\title{
И.В. Балюнов
}

\section{АРХЕОЛОГИЧЕСКИЕ СВИДЕТЕЛЬСТВА ВЛИЯНИЯ СЕВЕРО-ВОСТОЧНОЙ РУСИ НА МАТЕРИАЛЬНУЮ КУЛЬТУРУ НАСЕЛЕНИЯ ГОРОДА ТОБОЛЬСКА КОНЦА XVI - XVII в.}

\author{
Исследование проведено за счет гранта РНФ (проект № 14-28-00045).
}

\begin{abstract}
Статья посвящена изучению археологического материала, свидетельствующего о влиянии земель Северо-Восточной Руси на материальную культуру населения г. Тобольска конца XVI-XVII в. Установлено, что высококачественная посуда, а также некоторая часть изделий из черных металлов того времени являлись привозными из московских земель, а местное керамическое производство (гончарное, кирпичное, изразцовое), бронзолитейное и, вероятно, сапожное формировалось под влиянием ремесленных традиций центральной части страны.

Ключевые слова: Тобольск; Северо-Восточная Русь; материальная культура; XVII в.; влияние.
\end{abstract}

Город Тобольск, основанный в 1587 г., уже в конце XVI в. становится крупнейшим центром освоения Сибири. Через него в основном шло заселение русским населением территории, расположенной за Уралом, а кроме того, проходили торговые пути, связывающие Восток и Запад. Очевидно, что материальная культура жителей города испытывала разнообразное, в том числе аборигенное и иноземное, влияние (например, есть данные о торговле с немецкими городами, Средней Азией, Китаем). Однако проследить его на археологическом материале удается далеко не всегда. Традиционно считается, что освоение Сибири осуществлялось в значительной степени выходцами из Северной и Северо-Восточной Руси. Согласно данным, опубликованным О.Н. Вилковым, многие ремесленники, зафиксированные в Тобольске, были выходцами из городов именно этих регионов, но именно Северо-Восточная Русь оказала особое влияние на развитие целого ряда производств [1. С. 26], что находит подтверждение и в археологических материалах г. Тобольска конца XVI-XVII в.

Следует уточнить, что термин «Северо-Восточная Русь» не имеет в научной литературе строгого определения, поскольку его значение может меняться в зависимости от процессов административно-политической истории. Для указанного периода эти процессы уже не являются определяющими, и в настоящей публикации этот термин используется в самом широком географическом понимании, как центральные земли Московского государства и как некое противопоставление Северо-Западной и Юго-Западной Руси.

Самым массовым материалом, полученным при раскопках г. Тобольска, являются фрагменты гончарной посуды. Их изучение показало, что в этот период времени в городе бытовала преимущественно серокоричневая посуда, а более качественная темно-серая лощенная и поливная посуда, представленная единичными экземплярами, относится, очевидно, к привозной продукции. Как отмечает В.Ю. Коваль, главным произ- водителем до конца XVII в. чернолощеной посуды в границах Русского государства являлась Москва, хотя ее начинают изготавливать и в других крупных городах - Твери, Рязани, Владимире, а поливная посуда и вовсе изготавливалась, вероятно, только в Москве [2. С. 319]. Отдельно следует отметить находки двух поливных чернильниц. Первый экземпляр сохранился не полностью, имеет кубическую форму $(6 \times 6 \times 4$ см) $\mathrm{c}$ прямыми стенками, покрытыми геометрическим орнаментом (рис. 1, б). Аналогии, известные по раскопкам в Москве, позволяют определить находку как остатки настольной поливной чернильницы, состоящей из нескольких отделений, разделенных перегородками [3. С. 52 , табл. $18,10,12-18]$. Еще одна чернильница переносная, представлена находкой горлышка (покрыт светло-коричневой поливой, диаметром около 4 см), на котором видны два отверстия, очевидно, для продергивания шнура (рис. 1, 5). Подобные предметы также известны в московской археологической коллекции [Там же. С. 52-53, табл. 19, 1-3].

Изучение фрагментов серо-коричневой керамики показывает, что в Тобольске конца XVI-XVII в. горшок являлся наиболее распространенным видом керамической посуды. По форме венчиков выделяется значительное многообразие вариантов. Особо стоит отметить вариант (19\% от общего числа), когда венчик формировался путем смещения «черного края» внутрь (рис. 1,1$)$ (данный признак характерен для керамики «московских» земель) [4. С. 105-106].

На основе массовых находок и небольшого количества сосудов полного профиля можно сделать вывод, что в Тобольске в XVII в. имели распространение приземистые горшки (ширина по плечику всегда больше высоты) с маленьким дном, широким устьем, часто с покатым округлым плечиком, при этом переход от шейки к плечику выражен нечетко. Эти и некоторые другие признаки позволяют утверждать, что тобольская посуда имеет определенные сходства с керамикой 
того времени, происходящей из культурных слоев Москвы, Коломны и других соседних городов [2. С. 318-319; 4. С. 105]. Данная тема требует ещё дополнительной проработки и детального исследования, но уже сейчас можно обосновать предварительный вывод, что местное гончарное производство формировалось под влиянием ремесленных традиций, возникших в центральной части страны.

Особую категорию археологических находок образуют гончарные клейма, представленные тремя вариантами. Первый вариант включает в себя рельефные рисунки на донцах в виде солярного знака, напоминающего изображение колеса (окружность, в которую вписан многолучевой крест) (рис. 1, 2). Второй вариант образуют клейма с изображением прямоугольного креста, помещенного в окружность - «крест в круге» (рис. 1,3$)$. Третий вариант - прямоугольник, в который вписан косой (диагональный) крест, дополненный ли- ниями, исходящими из его углов (рис. 1, 4). Подобные клейма известны достаточно хорошо по материалам средневековой Руси, и, как считается, они отражают общую языческую славянскую символику, имеющую культовый характер и выражающую обоготворение, почитание неба и небесных светил. Очевидно, что известные рисунки тобольских клейм имеют достаточно архаичное происхождение, и, вероятно, в позднем Средневековье гончары могли уже не осознавать их первоначального (языческого) значения.

Особо стоит отметить, что на большей части русских земель традиция клеймения посуды заканчивается ещё в XIV в. и только иногда фиксируется на северовостоке Руси в XV-XVII вв. Как пример можно привести Тверь [5. С. 390], Суздаль [6. С. 128], подмосковный Дмитров [7. С. 198], где обнаружены аналогии трем вариантам гончарных клейм, известных по раскопкам в Тобольске.
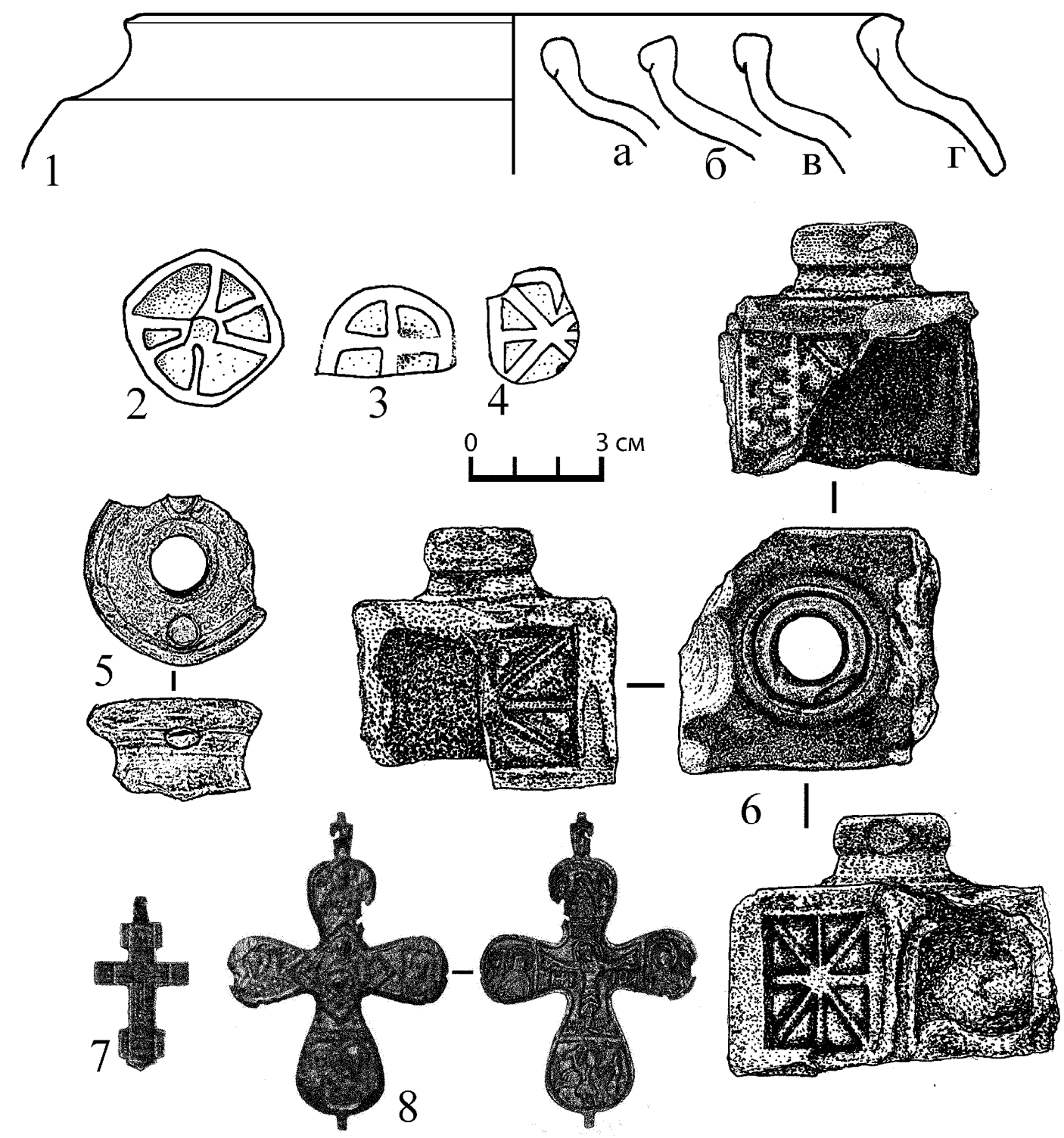

Рис. 1. Материалы археологических исследований культурного слоя города Тобольска:

1 - фрагменты венчиков горшков; 2, 3 - гончарные клейма; 5, 6- чернильницы; 7 - нательный крест; 8 - наперсный крест. 1-6-глина; 7, 8- бронза 
Продолжая тему керамического производства, следует отметить, что, согласно письменным источникам, каменное строительство в сибирском городе формировалось непосредственно под «московским» влиянием. Так, например, Софийский собор возводился приезжим зодчим и артелью устюжских каменщиков в 16811686 гг. по проекту, присланному из Москвы, что предопределило в дальнейшем развитие кирпичного дела, и чуть позднее в Тобольске появляется свое изразцовое и черепичное производство. Эти факторы также находят отражение в составе культурных напластований. В исследованиях А.В. Нескорова, посвященных изучению тобольских печных изразцов, они подразделены на несколько групп. Первую группу автор условно называет «московскими», поскольку их достаточно уверенно можно соотнести со столичными образами, и отдельно выделяются «тобольские», характеризующиеся уникальными самобытными сюжетами. И если для последних автор отмечает подчеркнутую реалистичность изображаемых предметов, то для первой группы, напротив, свойственны отсутствие детально проработанных сюжетов и некоторая небрежность рисунка. Сами сюжеты, передающие изображения птиц, животных, сцены охоты, воинов с различным вооружением, по мнению А.В. Нескорова, близки изразцам, распространенным в Москве и городах центральной части России [8. С. 400401]. Эти данные хорошо согласуются с наблюдениями, сделанными Р.Л. Розенфельдом, который занимался изучением изразцов непосредственно московского производства [3. С. 63].

Еще более ярко влияние Северо-Восточной Руси представлено в образцах металлопластики. Это можно показать на примере находки небольшого нательного креста (размером 22×41 мм) (см. рис. 1, 7). По мнению европейских исследователей, аналогичные кресты имели достаточно широкое распространение в XV-XVI вв. в тверской земле и прилегающей к ней территории [9. кат. № 2в; 10. С. 183]. Кроме этого, в тобольских материалах представлена находка наперсного двустороннего креста (размеры $73 \times 4,8$ см), покрытого достаточно сложными иконографическими сюжетами (см. рис. 1, 8). На лицевой стороне центральным сюжетом является образ Богоматери Знамения, на оборотной - Распятие. Тобольский крест находит многочисленные аналогии в европейских материалах [9. кат. № 26; 10. С. 92 и др.]; отдельно следует отметить находки двух крестов, обнаруженные во время исследований Старой Рязани В.П. Даркевичем, который высказывает предположение об их московском происхождении и датирует находки второй половиной XV в. [11. С. 229-230, рис. $3,7,8]$. Интересным отличием является то, что все известные европейские экземпляры при всей идентичности тобольской находки, как правило, отличаются расположением сторон.

Известные аналогии позволяют прийти к заключению, что как наперсные, так и нательные кресты описанного облика появляются на территории Москов- ского государства не позднее XV в. и получают широкое распространение на протяжении XV-XVI вв. Судя по археологическим находкам, подобные кресты использовались в Сибири в XVII в., а возможно, и в XVIII в. Эти и другие данные указывают на их местное производство, а кроме того позволяют говорить о том, что сибирские ювелиры и бронзолитейщики были носителями европейских традиций художественной металлообработки и, вероятно, на протяжении некоторого времени воспроизводили европейские образцы, которые в Центральной России являлись уже устаревшими. Ещё одной причиной, по которой местные мастера могли копировать «старые» образцы, является то, что в связи с событиями Смутного времени меднолитейное производство в Московском государстве в XVII в. переживало временный упадок.

Существуют отдельные категории археологических находок, которые не столь очевидно, как предыдущие, указывают на связь с землями Северо-Восточной Руси, поскольку вещи похожего облика имели достаточно широкое распространение. Например, это касается замков и ключей, которые были сложны в изготовлении для местных мастеров, занимавшихся только их починкой [1. С. 61, 88, 140]. В Тобольске найдены два небольших навесных замка с откидывающейся дужкой, аналогии которым известны в Москве и Тушино [12. рис. $8,9,11 ; 13$. С. 61].

К этому стоит добавить, что огнестрельное оружие поступало в Тобольск централизованными поставками из Москвы, тем более что основные центры его производства находились в границах Северо-Восточной Руси. В культурном слое сибирского города найдено большое количество свинцовых пуль, винты от ружейных замков, наконечники шомполов, которые по понятным причинам находят множество европейских аналогий [14. С. 13].

Заметное сходство со столичной обувью обнаруживает обувь, известная по материалам археологических исследований в Тобольске [15. С. 179-186], но в данном случае говорить о прямом влиянии следует также достаточно осторожно. Как пример можно привести находки туфель на невысоком деревянном каблуке, близким аналогом которым является образец из раскопок на ул. Арбат [16. С. 145, ил. 53], или сапоги на наборном кожаном каблуке - близким аналогом являются сапоги, найденные в Москве при раскопках Кадашевской набережной [Там же. С. 46, 153, ил. 69]. Кроме того, согласно исследованиям О.Д. Осипова, к началу XVII в. в Москве получают распространение модели с вытянутыми крыльями головки [Там же. С. 51], что характерно и для тобольской обуви этого времени. Кроме того, для сибирских образцов обуви жестких форм характерно использование на заднике декора из медной проволоки. Как указывает Д.О. Осипов, в конце XVIXVII вв. в Москве пяточный рант украшали желтой крученой проволокой, изготовленной из свинцовооловянистого сплава [Там же. С. 65]. 
Совокупность представленных материалов указывает на наличие тесной экономической и духовной связи г. Тобольска с городами Северо-Восточной Руси. Очевидно, что кроме переселенцев и товаров за Урал проникали и ремесленные традиции, которые оказали заметное влияние на становление и развитие производственной деятельности жителей сибирского города. Оценивая степень такого влияния, можно отметить, что археологические свидетельства влияния центральных земель Московской Руси на жизнь Тобольска выражены гораздо более явно, чем влияние других русских территорий. Это может показаться удивительным с учетом того, что общепризнанным фактом является процесс массового заселения Сибири выходцами из Северной Руси. Известно, что ранее северные земли находились под новгородским влиянием и были присоединены к Москве накануне «сибирского взятия». В связи с этим стоит обратить внимание на такой факт, что хронология древностей, детально разработанная на материалах раскопок Новгорода Великого, часто плохо применима для русских памятников за Уралом. В научной литературе неоднократно отмечалось, что такие вещи, как, например, гребни, светцы, кресала, навесные замки XVII-XVIII вв. и пр., известные по раскопкам в Сибири, согласно новгородской классификации, уже должны были выйти из употребления к этому времени [17. С. 93-95, 97; 18. С. 80-85]. У этих обстоятельств существуют различные объяснения, но можно, с одной стороны, предположить, что с Русского Севера шла мощная волна крестьянской (и, вероятно, промысловой) колонизации, а в торговопромышленном отношении Тобольск был теснее связан с землями Северо-Восточной Руси. С другой стороны, сделанные выводы нельзя еще принять как абсолютные. С учетом того, что позднесредневековые археологические памятники как в Европейской России, так и в Сибири изучены еще достаточно неравномерно, следует ожидать значительного уточнения и корректировки известных данных.

\section{ЛИТЕРАТУРА}

1. Вилков О.Н. Ремесло и торговля Западной Сибири в XVII в. М. : Наука, 1967. 324 с.

2. Коваль В.Ю. Керамическое производство в центральных районах России в XVII-XIX вв. // Культура русских в археологических исследованиях: междисциплинарные методы и технологии, Омск, 2011. С. 317-323.

3. Розенфельдт Р.Л. Московское керамическое производство XII-XVII вв. САИ. М., 1968. Вып. Е1-39. 124 с.

4. Коваль В.Ю. Белоглиняная керамика в средневековой Москве // Российская археология. 2001. № 1. С. 98-109.

5. Кобозева Е.В. Тверские гончарные клейма из раскопок 2007-2011 годов на Затьмацком и Загородском посадах // Археология Подмосковья: материалы научного семинара. М., 2014. Вып. 10. 370-392.

6. Несмиян О.А., Несмиян В.Г. Клейма на гончарных сосудах древнего Суздаля (по материалам раскопок на улице Слободской в 20102011 гг.) // Труды IV (XX) Всероссийского археологического съезда. 2014. Т. 3. С. 124-129.

7. Панченко К.И. Клейма ХІІ-ХІХ веков на донцах керамических сосудов из раскопок в городе Дмитрове // Археология Подмосковья. Материалы научного семинара. М., 2007. Вып. 3. С. 197-204.

8. Нескоров А.В. Тобольские изразцы как исторический источник (к постановке проблемы) // Русские старожилы. Материалы III Сибирского симпозиума «Культурное наследие народов Западной Сибири». Тобольск ; Омск, 2000.

9. Гнутова С.В., Зотова Е.Я. Кресты, иконы, складни. Медное художественное литье ХІ - начала ХХ века. Из собрания Центрального музея древнерусской культуры и искусства имени Андрея Рублева : альбом. М., 2000. 136 с. : ил.

10. Станюкович А.К., Осипов И.Н., Соловьев Н.М. Тысячелетие креста. Произведение русской христианской металопластики Х-ХХ веков из частных собраний. М., 2003. 260 с.

11. Даркевич В.П., Пуцко В.Г. Производство средневековой металлопластики из находок в Старой Рязани (1970-1978) // Советская археология. 1981. № 3. С. 218-232.

12. Никитин А.В. Русское кузнечное ремесло XVI-XVII вв. // Археология СССР. Свод археологических источников. М., 1971. Вып. Е1-34. 84 с.

13. Из глубины столетий. М. : Музей истории города Москвы, 1998. 64 с.

14. Балюнов И.В. Предметы вооружения из культурного слоя города Тобольска // Миллеровские чтения: финно-угорский мир в древности, в Средневековье и в настоящее время. Нижневартовск, 2015. С. 15-17.

15. Балюнов И.В. Обувь жестких форм из культурного слоя города Тобольска XVII века // Вестник Новосибирского государственного университета. Серия: История, филология. Новосибирск, 2012. Т. 11, вып. 7. С. 179-186.

16. Осипов Д.О. Обувь московской земли XII-XVIII вв. М. : ИА РАН, 2006. 207 с.

17. Визгалов Г.П., Пархимович С.Г. Мангазея: новые археологические исследования (материалы 2001-2004 гг.). Екатеринбург ; Нефтеюганск : Магеллан, 2008. $296 \mathrm{c}$.

18. Лобанов Н.А. Некоторые бытовые находки из Пскова // Краткие сообщения Института археологии. 1989. Вып. 195. С. $80-85$.

Balyunov Igor V. Novosibirsk State University (Novosibirsk, Russia). E-mail balyunoff@mail.ru

THE ARCHAEOLOGICAL EVIDENCE OF THE INFLUENCE OF THE NORTH-EASTERN RUSSIA ON THE MATERIAL CULTURE OF THE POPULATION OF THE TOWN TOBOLSK THE END OF XVI-XVII CENTURIES.

Keywords: Tobolsk; North-Eastern Russia; material culture; XVII century; the influence.

The town of Tobolsk was founded in 1587; it became the largest center for reclamation of Siberia at the end of the XVI century. Mainly through Tobolsk Russian population gone settling the territory located beyond the Ural Mountains, and in addition, trade routes connected the East and West. It is evident that material culture of the inhabitants of the town was experiencing a variety of indigenous and foreign influences. However, is not always possible to follow it on archaeological material. Traditionally it is considered that the opening up of Siberia was carried out largely by migrants from Northern and North-Eastern Russia, which is supported by the archaeological findings of Tobolsk the end of XVI - XVII centuries. The most widespread material received during the archeological excavations, are fragments of pottery. Their research demonstrates that a high quality dishes were brought to Tobolsk from the central part of the country, for example, irrigation inkwells. Perhaps in the town were the manufactures of ceramics, which shows a number similarities with pottery of the Moscow lands. A particular category of archaeological finds are pottery stamps. Such stamps are represented widely in the 
materials of medieval Russia, but in most parts of Russian lands the tradition of marking dishes finished in the XIV century or sometimes recorded in the northeast of Russia in the XV-XVII centuries. According to written sources, the stone construction in Tobolsk was formed immediately under "Moscow" influence. This impact was reflected in the brick and tile manufacturing in the Siberian town. The findings in Tobolsk of copper crosses reveal very accurate analogies with the samples from the European part of the Russia, although probably they were produced by local craftsmen. There are some categories of archaeological findings, which not as evident as the previous ones, indicate a relationship with the lands of the North-Eastern Russia. It is, for example, locks and keys, items of firearms equipment (bullets, parts of locks, ramrod tips), considering that things of similar shape were widely circulating at that time. Shoes from the archaeological excavations in Tobolsk, has a great similarity with the footwear from the capital, but in this case one should talk carefully about the direct influence. The collection of submitted materials indicates the presence of close economic and spiritual ties of Tobolsk with the towns of North-Eastern Russia. It is clear that besides migrants and goods across the Urals penetrated also craft traditions, which had a significant influence on the establishment and development of the productive activities of the residents of the Siberian town.

\section{REFERENCES}

1. Vilkov, O.N. (1967) Remeslo i torgovlya Zapadnoy Sibiri v XVII v. [Craft and trade in Western Siberia in the 17th century]. Moscow: Nauka.

2. Koval, V.Yu. (2011) Keramicheskoe proizvodstvo v Tsentral'nykh rayonakh Rossii v XVII-XIX vv. [Ceramic production in the central regions of Russia in the 17th - 19th centuries]. In: Tataurova, L.V. (ed.) Kul'tura russkikh v arkheologicheskikh issledovaniyakh: mezhdistsiplinarnye metody $i$ tekhnologii [Russian culture in archaeological research: Interdisciplinary methods and technologies]. Omsk: Russian State Economic University. pp. 317-323.

3. Rozenfeldt, R.L. (1968) Moskovskoe keramicheskoe proizvodstvo XII-XVII vv. [Moscow ceramic production the 12th - 17th centuries]. Issue E1-39. Moscow: Kniga po trebovaniyu.

4. Koval, V.Yu. (2001) White clay pottery in medieval Moscow. Rossiyskaya arkheologiya - Russian Archeology. 1. pp. 98-109. (In Russian).

5. Kobozeva, E.V. (2014) [Tver pottery marks from excavations of 2007-2011 in Zatmatskom Zagorodsky Posad]. Arkheologiya Podmoskov'ya [Archeology of Moscow Region]. Proc. of the Research Seminar. Moscow. pp. 370-392. (In Russian).

6. Nesmiyan, O.A. \& Nesmiyan, V.G. (2014) Kleyma na goncharnykh sosudakh drevnego Suzdalya (po materialam raskopok na ulitse Slobodskoy v 2010-2011 gg.) [Pottery marks on vessels in Ancient Suzdal (based on excavation in Slobodskaya Street in 2010-2011.)]. Trudy IV (XX) Vserossiyskogo arkheologicheskogo s"ezda. 3. pp. 124-129.

7. Panchenko, K.I. (2007) [Pottery marks of the 12th - 19th centuries on the bottom of ceramic vessels from excavations in Dmitrov]. Arkheologiya Podmoskov'ya [Archeology of Moscow Region]. Proc. of the Research Seminar. Moscow. pp. 197-204. (In Russian).

8. Neskorov, A.V. (2000) [The Tobolsk tiles as a historical source (on the problem)]. Russkie starozhily [Russian old-timers]. Proc. of the Third Siberian Symposium. Tobolsk; Omsk. (In Russian).

9. Gnutova, S.V. \& Zotova, E.Ya. (2000) Kresty, ikony, skladni. Mednoe khudozhestvennoe lit'e XI - nachala XX veka. Iz sobraniya Tsentral'nogo muzeya drevnerusskoy kul'tury i iskusstva imeni Andreya Rubleva [Crosses, icons, folding icons. Copper art castings of the 11th - early 20th centuries. From the collection of the Central Museum of Ancient Russian Culture and Art named after Andrei Rublev]. Moscow: Interbuk-bizness.

10. Stanyukovich, A.K., Osipov, I.N. \& Soloviev, N.M. (2003) Tysyacheletie kresta. Proizvedenie russkoy khristianskoy metaloplastiki X-XX vekov iz chastnykh sobraniy [The millennium of the cross. Russian Christian metal artworks of the 10th -20th centuries from private collections]. Moscow: Raritet.

11. Darkevich, V.P. \& Putsko, V.G. (1981) Proizvodstvo srednevekovoy metalloplastiki iz nakhodok v Staroy Ryazani (1970-1978) [Medieval metal plastic finds in Old Ryazan (1970-1978)]. Sovetskaya arkheologiya. 3. pp. 218-232.

12. Nikitin, A.V. (1971) Russkoe kuznechnoe remeslo XVI-XVII vv. [Russian blacksmithing in the 16th -17 th centuries]. Arkheologiya SSSR. Svod arkheologicheskikh istochnikov. Issue E1-34. Moscow.

13. Museum of History of Moscow. (1998) Iz glubiny stoletiy [From the depths of centuries]. Moscow: Museum of History of Moscow.

14. Balyunov, I.V. (2015) Predmety vooruzheniya iz kul'turnogo sloya goroda Tobol'ska [Armory of the cultural layer of Tobolsk]. In: Solodkin, Ya.G. \& Choref, M.M. (eds) Millerovskie chteniya: finno-ugorskiy mir v drevnosti, v srednevekov'e i v nastoyashchee vremya [The Miller Readings: The Finno-Ugric world in ancient times, Middle Ages and now]. Nizhnevartovsk: Nizhnevartovsk State University. pp. 15-17.

15. Balyunov, I.V. (2012) Obuv' zhestkikh form iz kul'turnogo sloya goroda Tobol'ska XVII veka [The footwear of rigid forms in the cultural layers of Tobolsk in the 17th century]. Vestnik Novosibirskogo gosudarstvennogo universiteta. Seriya: Istoriya, filologiya - Vestnik Novosibirsk State University. History and Philology. 11(7). pp. 179-186.

16. Osipov, D.O. (2006) Obuv' moskovskoy zemli XII-XVIII vv. [The footwear in Moscow region in the 12th-18th centuries]. Moscow: Institute of Archeology.

17. Vizgalov, G.P. \& Parkhimovich, S.G. (2008) Mangazeya: novye arkheologicheskie issledovaniya (materialy 2001-2004 gg.) [Mangazeya: New archaeological research (2001-2004)]. Ekaterinburg; Nefteyugansk: Magellan.

18. Lobanov, N.A. (1989) Nekotorye bytovye nakhodki iz Pskova [Some household finds from Pskov]. Kratkie soobshcheniya Instituta arkheologii. 195. pp. 80-85. 